\title{
Scene Design: First as a Methodology then as a New Professional Field
}

\author{
Milićević, Slađana
}

Faculty of Technical Sciences, University of Novi Sad, Serbia.

\begin{abstract}
This work depicts the way in which the term of scene design is formed, used and developed in professional and educational system in the Republic of Serbia. The introductory part presents what that term means, how it was made and how it has evolved since the 90s. The main part of the work by means of particular examples shows how scene design was first a specific methodology in educating the students of architecture at the Department of Architecture and Urbanism at the Faculty of Technical Sciences in Novi Sad, then how establishing the studies of scene design at the same faculty made this methodology evolve into the professional field, where new and authentic research methods relating space emerged. Method of performing is outlined and analysed as one of that new methods, formed in the processes of contemplation, articulation, and realisation of performing space through different subjects of the curriculum of new scene design studies. The goal of the work is to show the potential of this method for thorough research not only of performing space but space in general. Likewise, to show how this method could be a valuable tool in educating not only scene design and architecture students, but all the other educational profiles interested in spatial research and spatial design.
\end{abstract}

Keywords: scene design; architecture; methodology; performing; performing space. 


\section{Introduction}

The emergence of scene design in the Republic of Serbia is related to the activities of YUSTAT - Yugoslav Society for Theatre Art and Technology, established during the 90s with the idea to improve "quality of professional production in performing arts", as well "to make visible all of the individual and collective efforts that theatrical people make in the world 'behind scene', or to show what all performing event is, what it could be, or in relation to that, where all we can recognize performance or performing space" (Dinulović, 2010). In order to realize these goals, YUSTAT run Biennial of Scene Design in 1996 when the term scene design was used for the first time, and when it was officially established. Theatre architect, professor and founder of the studies in the field of scene design Radivoje Dinulović did the most for the term of scene design to be incorporated into the Serbian language. He wrote in a wide number of his works what the term refers to and what its etymological role model was. Dinulović especially emphasizes his encounter with scenographer Pamela Howard and the influence her understanding of scenography and performing space made on him. In the essay 'Expanded scenography', or what is scene design? he wrote: "It seems to me that Pamela Howard was the first to introduce the word Scenography into the modern English language ... in order to emphasize her unambiguous conviction that the term 'scenography' does not refer only to the creation of décor (Stage Design, or Set Design), but implies contemplation, articulation and realization of the whole stage design - including its visual, auditory, tactile, as well as all other sensory aspects - in one word, scenography is a kind of approach that belongs to the theatre understood not as 'a play for seeing' (Schauspiel), or 'a play for hearing' (Hörspiel), but as 'an interplay' (Mitspiel)" (Dinulović, 2010). Seeking to make visible the same difference in professional practice in Serbia, but confronting the fact that the word scenography has already been in use in Serbian language, Dinulović, Milosav Marinović, and Irena Šentevska introduced a new term - scene design. In hindsight, the term has evolved notably since the beginnings and beside its primary meaning - a specific synthesis approach to creation of performing space in theatre, it also got a number of other different readings. Theorist of scene design Tatjana Dadić Dinulović wrote that scene design nowadays is "a unified process of thinking, creating and realization of a stage design in the widest sense of that word, or, a process of creating complex, synthesis environment, physical or metaphorical, where the stage design can be built, thought of, or be found in a much wider space than theatre itself" (Dadić Dinulović, 2017). She points out the fact that today scene design stops to be exclusively theatrical phenomenon, and that it can be identified within different professional and artistic practices, curatorial practices, within theory and critics, but also everywhere where it is possible to implement a theatrical way of thinking or to apply a structural logic inherent to the performing space (stage plus auditorium). Eventually, besides being specific way of thinking or tool for creating of performing space in theatre or 
non-theatre practices, scene design appears also to be an extremely effective means of the research of space in general.

\section{Scene Design as a Methodology}

Space has always been a central preoccupation for architects, but only after the influence of the Modern Movements the architecture will essentially be defined as the art of spatial design. Architecture as space becomes a distinctive mark of the 20th century architecture, while space becomes central issue in learning, understanding or creating of architecture. This is how manipulating the space and its presentation have come to be in the main focus of modern architects rather than presenting facades or the architectural styles. However, over the time, and especially after the postmodern critique of the late modern formalism, the phenomenological reflections on the bond between man and space, or after the emergence of so-called spatial turn at the end of the century, complexity of the role that space has in human life will finally become apparent. Today, pointing to this complexity and finding the ways to explore and understand it the most directly, are among the main pedagogical challenges in the education of architecture students. Simultaneously, this challenge proved to be an impetus for methodological inventiveness in dealing with space, and specially for the development of different interdisciplinary approaches.

Scene design as methodology can exactly be recognized as a such interdisciplinary approach, where the intent was to combine the theatrical way of thinking and understanding of space with the architectural environmental analysis. In the education of architecture students this approach provided an opportunity for profound and more intimate understanding of the bond between the space and the user. In theatre, the space is the key element of a play, which is underlined by the words of the theatre architect and director Meta Hočevar, who says that: "nothing could happen without happening somewhere" (Hočevar, 2003). This means that space provides authenticity and credibility of the story, and allows the story as such to happen. Understanding of this existential dimension of space for architecture students meant very important confrontation with the fact that space is not an abstraction, but very often a key actor - “dramatic character" (Milićević, 1980) - of the life process happening in it. After being using scene design students of architecture have no longer considered only proportions, forms and materiality of architectural space, but some new and for them even more important questions: the relation between body and space, narrative and space, time and space, dramatic and scenic potential of space.

For the first time in the Republic of Serbia, scene design was implemented as a research method in dealing with space in the education of architecture students at the Department for Architecture and Urbanism (Faculty of Technical Sciences at the University of Novi Sad). The first realised project named Essay was initiated by the students of different years of 
undergraduate studies, who under the mentorship of professor Radivoje Dinulović and theatre director Ljubomir Draškić performed their works in different space of the faculty building in 1999 (Dadić Dinulović, 2017). In the years that followed, the course Architectural Design was principally the place where scene design was tested and gradually implemented into the official curriculum of architectural studies. Scene design was at times a kind of methodology within the practical classes, and at times a specific way of thinking about space and contemporary architecture. But, the first systematic and formal use of scene design was within the subject Introduction to Architectural Design on the first year of undergraduate studies. During the workshops organised within this course the students designed and physically built small performing events for/in different space at the faculty and in the city. The aim of these workshops was to establish and explore the link between (performing) event and space, or (performing) event and an experience of space. For students, who were at the beginning of their studying of architecture and surrounding space, this task was a valuable step forward to meet the architecture and a creative introduction to their future profession. Thus, the workshops employed ,a form of non traditional thinking in order to adequate form of studying architecture be discovered“ (Babić, Balzam, 2012).
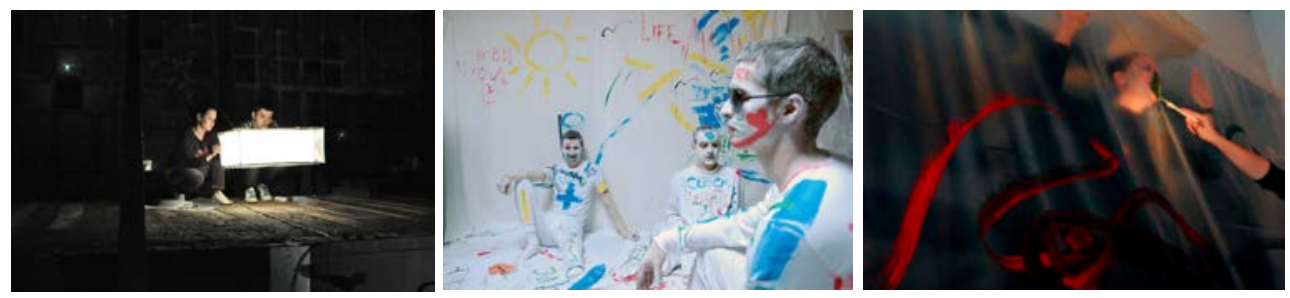

Figure 1. To Europe, by Boulevard? (2010) and Faces of the City (2011), projects at the course Introduction to Architectural Design at the undergraduate studies Architecture and Urbanism.
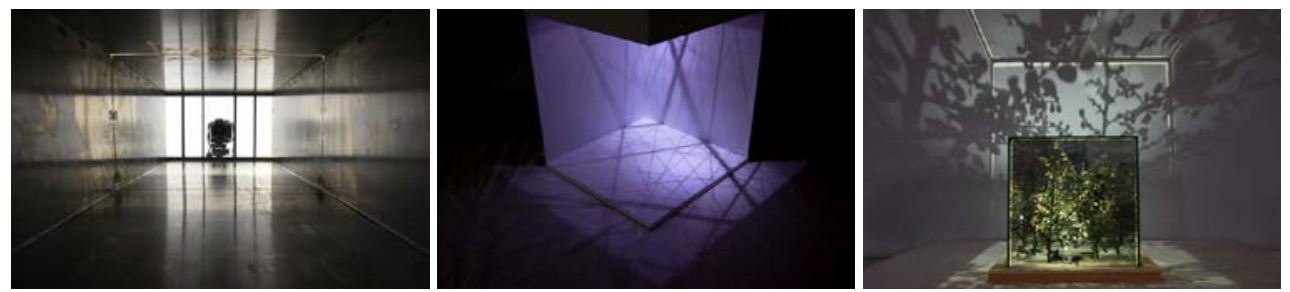

Figure 2. Story Space and Personal Space of Tonio Kröger 2012/2013, project at the course Architectural Design 1 at the undergraduate studies Architecture and Urbanism.

At the course Architectural Design 1, in the third year of architecture studies, the scene design as methodology was implemented through the tasks having reading some dramatic texts in their focus, then translating dramatic space from those texts into the spatial concepts finally materialised as different forms of three-dimensional models (maquettes). A distinctive part of these tasks was exhibiting the representative maquettes in public space, organisation and curation of the exhibition at the end of the semester. That part students 
found to be completely new way of dealing with real space and impetus for new research of relations between space and performance, architecture and event.

The platform for implementation of the scene design as methodology into the process of research of architecture and urban planning at the doctoral studies of Architecture since 2012 has been the course Theoretical and Creative Research in Architecture and Urbanism. A part of this was the first realised project where students questioned relations between their inner imaginary spaces and real physical spaces of their immediate surroundings. During this process the scene design was used as a means for translation of abstract spatial experiences into the real spatial concepts. Spatial installations, as the final outcome of this project, were exhibited at the Students Cultural Centre of Novi Sad as a part of the side programme of the $39^{\text {th }}$ International Festival of Alternative and New Theatre. The real specificity of this project is a fact that scene design was used as a tool during the process of creation of the displayed works, while these works by themselves could partly be characterised as independent works of scene design as art. Therefore, this project is important because it is among the first at the Department of Architecture and Urbanism in which it is possible to follow this twofold function of scene design: first as a tool for artistic research, then as independent artistic practice.
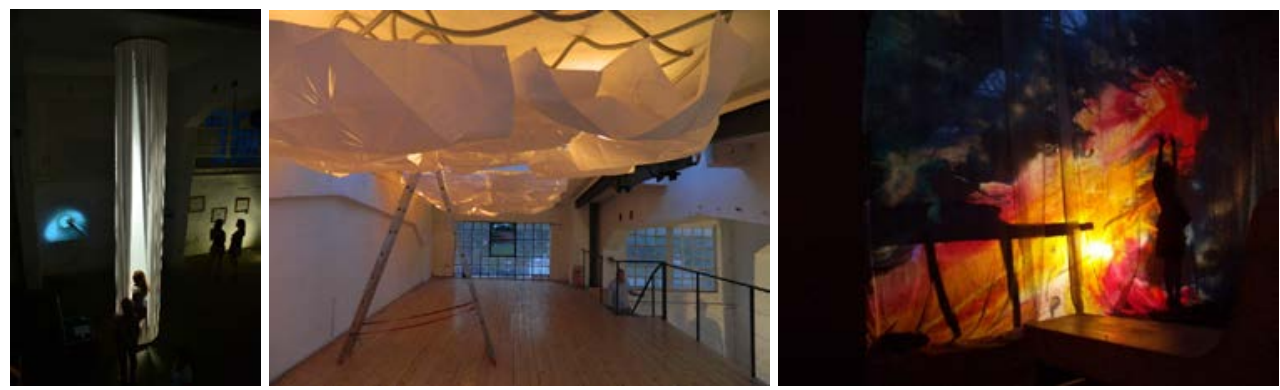

Figure 3. Inside (2012), project at the course Theoretical and Creative Research in Architecture and Urbanism at the doctoral studies of Architecture.

\section{Scene Design as a New Professional Field}

The Scene Design Group at the University of Arts in Belgrade was an academic format where scene design could have been studied for the first time in the Republic of Serbia at the level of magister or doctoral studies. These studies existed from 2001 to 2008, and during these years more than one hundred students were studying scene design (Dadić Dinulović, 2017). In 2013 at the Department of Architecture and Urbanism at the Faculty of Technical Sciences new study programmes in the field of scene design were formed, but 
this time on all three academic levels - undergraduate, master, and doctoral. ${ }^{1}$ Since the last year the studies of scene design have been a part of the Section for Art and Design at the Faculty of Technical Sciences. These studies are unique in their character because of the inconvenient mixture of science and art, architecture and theatre. The studies are interdisciplinary and allow students to gain different knowledge and skills. Simultaneously, this approach requires contemporary, active attitude to studying and independence in professional orientation. At the undergraduate studies of Scene Architecture, Technique and Design students have the opportunity to orient themselves toward the three main areas: scene architecture, scene technique and technology, and scene design. Master studies of Scene Architecture and Design are dedicated to the different levels of analysis and interpretation of artistic components of performing space, while the doctoral studies are exclusively focused on the phenomenon of scene design as art. Eventually, by establishing these studies, after more than one decade of application of scene design as methodology at the school of architecture in Novi Sad, scene design today is finally being studied and developed as an independent field.

The studies of scene design still have space at their main focus, explore the relations between architectural and performing space, or physical space and performing event. But, in terms of methodology, approaching the space become wider and strikingly more complex. Methodological diversity was primarily generated by interdisciplinary and experimental character of the studies themselves. On the other hand, in the last four years of the studies of scene design being in existence, one method proved to be the most essential and primarily important for the field of scene design. This is the method of performing. This method in its character is at the same time a kind of research and a mode of representation. This ambiguity on one hand refers to the practice of performing, the processual nature of creative research in performing arts, while on the other it refers to the performance itself that finally appears as a product of the practice of performing. It means that the performance is a material product of the process of performing (Šuvaković, 2005). The performing as a teaching method at the studies of scene design implies both of these meanings. The most of student works are by themselves performing events shown to the audience (teaching collective, other students or general public). But, these works very often also emerged in performing, as side effect of performing. In the second case, we speak of "the performing as research method" ${ }^{2}$ (Ponjavić, 2016), while in the first we have the performing as a method of representation.

\footnotetext{
${ }^{1}$ The most teachers lecturing today at the new studies programmes of scene design in Novi Sad earned their PhD diplomas at the Scene Design Groupe at the University of Arts in Belgrade.

2 Monika Ponjavić uses this term in examination of her artistic work Body never lies, realised at the Faculty of Architecture, Civil Engineering and Geodesy at the University of Banja Luka within the course Buildings of Spectacle. That was the project where
} 

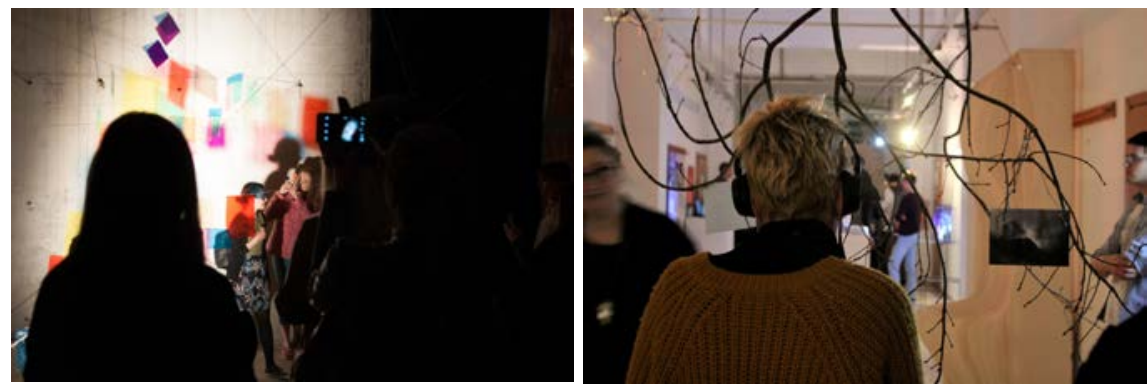

Figure 4. Synthesis Project (2017), Reading of Space (2017), projects at the undergraduate studies of Scene Architecture, Technique and Design.
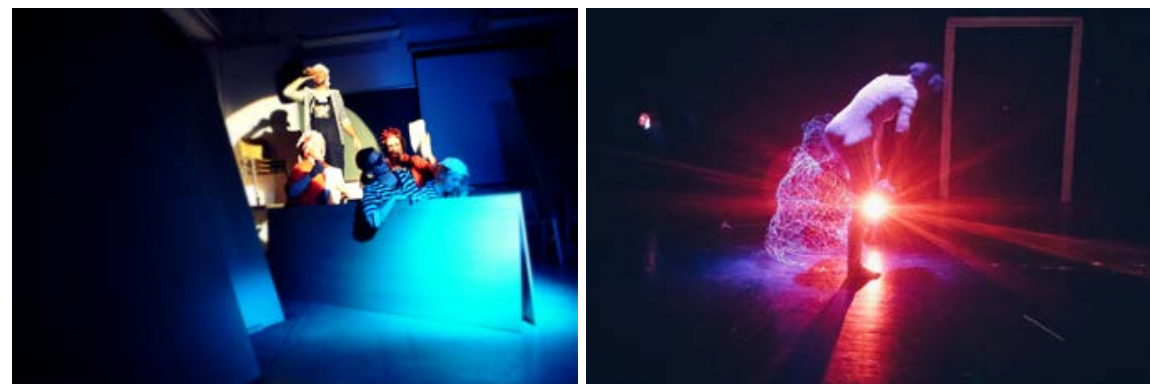

Figure 5. King Ubu (2015), project at the master studies of Scene Architecture and Design and the performing of the student work at the course Scene Movement 1 at the undergraduate studies of Scene Architecture, Technique and Design (2016).
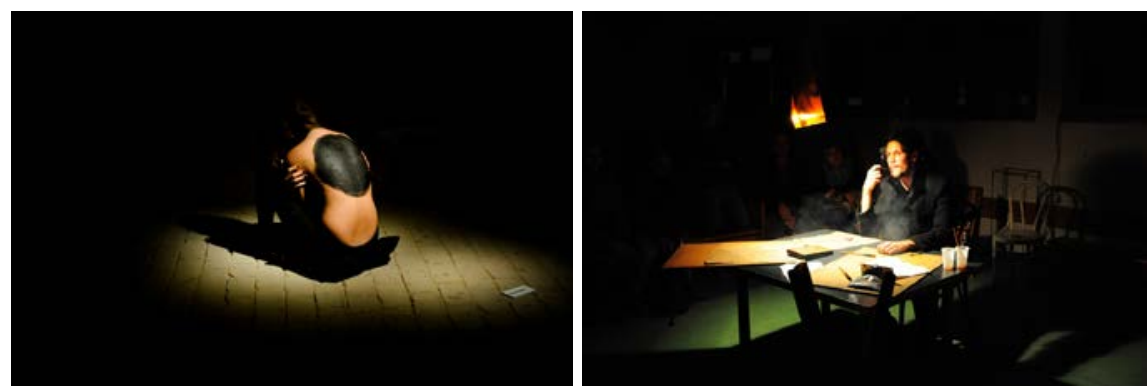

Figure 6. Synthesis Project (2016), Winning the Play Space (2015), projects at the undergraduate studies of Scene Architecture, Technique and Design.

Finally, while having in mind the well-known fact that performing space appears only when there is one man (actor) who performs something for another man (audience) it becomes clear why the performing is the beginning and the end of each articulation of performing space. It is also understandable why performing is a dominant methodological approach in

scene design was used as a teaching method in the analysis of architectural and city space, but first of all in the research of relations between body and space, i.e. body in space. 
the teaching of scene design, regardless of whether this is performing as research method or performing as representation.

\section{Conclusion}

The dynamics of development of scene design in the last twenty years at the school of architecture in Novi Sad shows that from today's perspective scene design could be seen as a kind of methodology, but also as a professional practice. While it should be born in mind that in historical terms scene design was in the first place methodology, and only then an independent professional activity. Eventually, it means that in the beginning scene design was used as a tool in different disciplines, but also that in the end, after constituting itself as a new discipline, it started creating its own tools and for that purpose using those disciplines it originated from - architecture, theatre, visual arts etc. This fact, finally, makes scene design a powerful means for different interdisciplinary approaches related to space, to designing and creating a variety of performing events, and especially for improving contemporary teaching practices in higher education.

\section{References}

Babić, T; Balzam, R. (2012). 'Istraživanje kroz projekat' - novi oblik učenja arhitekture i savremene arhitektonske prakse (Research by Design - New Way of Learning of Architecture and Contemporay Architectural Practice). Proceedings / IV International Symposium for Students of Doctoral Studies in the Fields of Civil Engineering, Architecture and Environmental Protection - PhIDAC 2012. Faculty of Civil Engineering and Architecture. Niš.

Dadić Dinulović, T. (2017). Scenski dizajn kao umetnost (Scene Design as Art). Klio\&Scen. Belgrade.

Dinulović, R. (2010). 'Proširena scenografija' ili šta je scenski dizajn? ('Expanded scenography' or what is scene design?). Available: http://www.scen.uns.ac.rs/wpcontent/uploads/2013/10/Pro\%C5\%A1irena-scenografija-ili-\%C5\%A0ta-je-scenskidizajn.pdf

Hočevar, M. (2003). Prostori igre (Play Spaces). Jugoslovensko dramsko pozorište. Belgrade.

Milićević, O. (1980). Prostor, dramsko lice (Space, Dramatic Character). Sterijino pozorje. Novi Sad.

Ponjavić, M. (2016). Tijelo nikad ne laže: Transponovane uloge prostora i tijela (Body Never Lies: Transposed Roles of Space and Body). Scena. 1-2. 231-238. Available: http://www.pozorje.org.rs/scena/scena1612.pdf

Šuvaković, M. (2005). Pojmovnik suvremene umjetnosti (Glossary of Contemporary Art). Horetzky. Zagreb. 